\title{
ASSESSING THE IMPACT OF INFLUENCING FACTORS ON THE QUALITY OF LOCAL GOVERNMENT FINANCIAL STATEMENTS
}

\author{
DOI: 10.17261/Pressacademia.2020.1176 \\ JEFA- V.7-ISS.1-2020(1)-p.1-8
}

\section{Khoirul Aswar}

Universitas Pembangunan Nasional Veteran, Jakarta, Indonesia.

Jl. Duren Tiga Barat V No. 6, Kelurahan, Duren Tiga Kecamatan, Pancoran, Jakarta Selatan. aswar law@yahoo.com , ORCID: 0000-0003-2508-1161

\begin{tabular}{l}
\hline Date Received: Decembber 12, $2019 \quad$ Date Accepted: March 2, 2020 \\
\hline To cite this document \\
Aswar, K. (2020). Assessing the impact of influencing factors on the quality of local government financial statements. Journal of Economics, \\
Finance and Accounting (JEFA), V.7(1), p. 1-8. \\
Permemant link to this document: $\underline{\text { http://doi.org/10.17261/Pressacademia.2020.1176 }}$ \\
Copyright: Published by PressAcademia and limited licenced re-use rights only. \\
\hline
\end{tabular}

\section{ABSTRACT}

Purpose- This study to investigate the relationship between internal control systems, information technology, Implementation of Government Accounting Standards and the quality of financial statements in Indonesia local government.

Methoodology- Data collection in this study based on a structured questionnaire sent to regional work unit of 75 local government unit tools of the 8 districts and city Banten Province of Indonesia. The insturment for contract and content reliability and validity was tested. Then, the hypothesis were tested using multiple linear regression.

Findings- The results indicated that intenal control system, information technology has a significant effect on the quality of financial statement in Indonesia local governments, whereas implementation of government accouting standards has not significant relationship with the quality of financial statement in Indonesia local governemnt. Though the study had contributed in extending the quality of financial statements of local government in Indonesia. Due to the local government that prepared financial statement do not same treatment in every similar event from one period to another. This is also generally due to the limited ability of human resources owned by local governments. Conclusion- This study concluded that intenal control system, information technology are positve significantly on the quality of financial statements in local government. Whereas, the implementation of government accounting standards insignificant relationship with the quality of financial statements in Indonesia local government. Therefore, further studies could be conducted to include other variables such as internal audit, competency etc and other local government in Indonesia.

Keywords: Internal control systems, information technology, implementation of government accounting standards, quality of financial statements.

JEL Codes: M41, M48, H11, G38

\section{INTRODUCTION}

Technological and economic developments in each country require good governance. Good governance is a form of success in carrying out the task of building the country in accordance with planned goals. Good governance requires government to be carried out by following the principles of good management such as transparency and accountability. One concrete form to realize transparency and accountability in the management of state finances is the enactment of Law No. 17 of 2003 concerning State Finance which requires the form and content of accountability reports on the implementation of the State Budget (APBN) /Regional Revenue and Expenditure Budget (Regional Budget) APBD) is prepared and presented in accordance with government accounting standards concerning by government regulations.

According to the results of the Supreme Audit Board (Badan Pemeriksa Keuangan = BPK) of 2017 shows 539 local government financial statements giving unqualified opionion $47 \%$. Based on the development of BPK's opinion on the local government financial statements from the previous year it has actually experienced an increase but it is still not as expected, this is due 
to there is still a disclaimer opinion 6\%. BPK still finds a number of problems related to the information disclosed in the financial statements and this has an effect on the quality of financial statement, so the quality of local government financial statements is still questionable (Ihps, 2017).

The local government financial statements that get the results of the unqualified opinion by the BPK when viewed from the internal control systems show that the weakness of internal control systems is $50 \%$ consisting problems with the accounting and reporting control system, weaknesses in the control system for implementing the revenue and expenditure budget, and internal control structure. Furthermore, the onother problem also arises with non-compliance with the laws and regulations valued at Rp 19.19 billion, which has a financial impact. The implementation of Government Accounting Standards in the local governments which was not yet suitable turned out to be that there were still local government financial statements that had decreased $4.16 \%$ (BPK, 2017).

Based on the BPK examination of financial statements in the district government in Banten Province, it is said that the factors that influence the quality of financial statements are the follow up on the internal control systems, information technology, the implementation of government accounting standards. The regional government is expected to be able to improve the quality of the financial statements in accordance with the follow-up to the financial audit. Improving the quality of local government financial statements is expected to have implications for good governance.

Internal control systems is an action and activity that is carried out continuously by the leadership and all employees to provide an adequate confidence in the achievement of organizational goals through effective and efficient activities, reliability of financial statements, security of state assets, and adherence to laws No. 60 of 2008 (Sari, 2012). There are a few studies related to the internal control systems, the results show that internal control system has a positive significant relationship with the quality of financial statements (Angus \& Mohammed, 2011; Muhammed et al. 2011; Kewo \& Afiah, 2017; Sari, 2012).

Information technology is other factor on the the quality of financial statements. Local governments are obliged to develop and utilize advances in information technology in order to improve local financial management, channel regional financial information to the public (PP No.56 of 2005). There some previous studies related to the information technology, the results reveal that the use of information technology has a significant relationship on the quality of financial statements (Liyan, 2013; Zadeh, Karkon \& Golnari, 2015; Medina-Quintero, Mora \& Abrego, 2015; Lim, 2013; Bakri, 2016; Sacer \& Oluic, 3013).

Implementation of government accounting standard is necessary so that financial statements presented by the government can be compared, and with the similarity of perception and understanding between financial statement presenters, financial statement users and financial statement supervisors (Sari, 2012). There are some of studies related to the effectof implementation of government accounting standard such as research conducted by Sari (2012), Sousa, Vasconcelos, Caneca, and Niyama (2012), Mahaputra and Putra (2014), where the results of the study state that the implementation of government accounting standards positively influence the quality of financial statement. While research by Inapty and Martiningsih (2016) states that the implementation of government accouting standard has no relationship with the quality of local government financial statement. Based on the description above, the purpose of this study is to examine whether internal control systems, information technology, implementation of government accounting standards have a positive relationship with the quality of local government financial statements.

With a focus on quality of financial statements in Indonesia local government context, the next section is highlights literature review related to the quality of financial statements, internal control system, information technology, and implementation of government accounting standard.

\section{LITERATURE REVIEW}

\subsection{Quality of Financial Statements}

According to Mardiasmo (2009) states that the quality of financial statements in the public sector must be able to present relevant and reliable financial information. the quality of financial statements is to provide fair information and present the state of the entity that is useful for users of financial statements (Wood \& Horner, 2010). Furthermore, Brookson (2009) defines the quality of financial statements as the results of an entity's operations in accordance with accounting standards at the end of the period. The quality of financial reporting provides information about the characteristics of financial information and the characteristics of information quality that are useful for its use (Jonas \& Blanchet, 2000; IPSAS, 2010).

Criteria and elements forming the quality of financial statement mentioned in the Conceptual Framework for Government Accounting consisting: (1) relevant (2) reliably (3) comparable, and (4) understandable (PP No. 71 of 2010). Otherwise, 
O'Briens and Maracas (2010) state that the quality of accounting information consists of three dimensions: accuracy, timelines and relevance. Meanwhile, Madison (2010) states that the quality of financial statements must be understandable, relevant, reliable and comparable. According to Van Beest et al. (2009); International Public Sector Accounting Standards (IPSAS, 2010) that the quality of financial statements can be seen by: relevance, faitful representation, understandable, comparative, schedule. Furthermore, IPSAS (2010) in the conceptual framework that the faithful representation, neutrality, and completeness are identified as components of reliability.

Financial statements are used to make economic decisions and ensure the reliability of financial statements (Boynton et al., 2006; Arens et al., 2014). This is in 3inet hat the financial statements that have been prepared in accordance with the standards related to operating results, the number of surpus or deficits must be stated fairly to guarantee audit opinions (Cohen \& Kaimanakis, 2011). So as the audit report will prevent the quality of financial statement information is low.

\subsection{Internal Control System}

Committee of Sponsoring Organizations of the Treadway Commission (COSO, 2013) defines internal control as "a process, which is influenced by the entity's board of directors, management and other personnel, which is designed to provide reasonable guarantees regarding the achievement of objectives relating to operations, reporting, and obedience". Boynton et al. (2006) said: Control of safeguarding assets against unauthorized acquisition, use and disposition. Internal control consists of organizational plans and all coordination steps and methods adopted in business to protect assets, check the accuracy and reliability of data accounting, encourage operational efficiency, and encourage compliance with specified managerial policies (Sawyer, 2003; Law No 60/2008).

Internal control suggested by Konrath (2002), cited by the American Institute of Certified Public Accountants professional Standards, describes that internal control is the mechanism followed by management, the board of directors, and staff of the organization is intended to provide fair assurances as the achievement of the goals in the following criterias: monitoring of the use of effectively and efficiently the entity's resources, control of financial reporting relating to the reliabliilty of financial statements, compliance controls relating to the applicable regulations and laws.

\subsection{Infromation Technology}

Government Regulation No. 56 of 2005 concerning Financial Information Systems states that the central government and local governments are obliged to develop and utilize advances in information technology to improve financial management capabilities, and distribute financial information to the public. Utilization of information technology includes data and information processing, management systems and work processes electronically and the use of information technology advancements so that public services are easily accessed by all users of the information (Desimone, 2017).

\subsection{Implementation of Governemnt Accounting Standard}

Government Accounting Standards are accounting principles used in the preparation and presentation of government financial statements and government accounting standard is a requirement that has the legal force to improve the quality of government financial statements (Bastian, 2010). Accounting standards are needed so that financial reports produced by the government can be compared, and there is a common perception and understanding between the presenters of financial statements, users of financial statements and supervisors of financial statements (Mardiasmo, 2009).

\subsection{Hypothesis Development and Conceptual Schema}

Hypothesis development will be based on the factors that allegedly possess an influence on the quality of local government financial statements, which is formulated as follows:

\section{Internal control system on the quality of financial statements}

The purpose of internal control systems in according to Warren et al (2005), one of which is to check the accuracy and reliability of accounting data. An accounting system, the risk of mistakes and recording or calculation errors can be minimized, thereby reducing the possibility of local governments experiencing errors. One part in the accounting information system that supports the smooth working of the accounting information system is internal control. Previous studies were conducted by Angus and Mohammed (2011), Muhammed et al. (2011), Kewo and Afiah (2017) Sari (2012) examined the effect of internal control systems on the quality of financial statements. The results of previous studies found that the internal control system significantly influences the quality of financial statements. Based on the above presumptions, the below hypothesis is formulated: 
$\mathrm{H}_{1}$ : Internal control systems significantly and positively influences the quality of local government financial statements

\section{Information technology on the quality of financial statements}

Utilization of information technology in financial data will provide benefits in the preparation of financial statements related to accuracy and flexibility (Sacer \& Oluic, 2013). The accuracy of financial data will increase and errors can be minimized when utilizing information technology. This assumption is made because the information technology is one of the factors that influence the quality of financial statements. Some previous studies showed that information technology has a positive and significant relationship on the quality of financial statements (Bakri, 2016; Lim, 2013; Liyan, 2013; Medina-Quintero, Mora \& Abrego, 2015; Sacer \& Oluic, 3013; Zadeh, Karkon \& Golnari, 2015). Therefore, based on the foregoing presumptions, the following hypothesis is stated:

$\mathrm{H}_{2}$ : Information technology significantly and positively influences the quality of local government financial statements.

Implementation of Government Accounting Standard on the quality of financial statements

Government Accounting Standards are accounting principles used in the preparation and presentation of government financial statements. Thus, standard is a requirement that has legal force in an effort to improve the quality of government financial statements in Indonesia (Bastian, 2010). According to Sari (2012) implementation of government accounting standard is needed so that the resulting financial statements can be compared and there is a common perception and understanding between the presenters of financial statements with users of financial reports and financial statement supervisors. Previous studies conducted by Sari (2012), Mahaputra and Putra (2014), and Sousa et al (2012) examined the effect of the implementation of government accounting standards on the quality of financial statements. The results of previous studies stated that the implementation of government accounting standards significantly influence the quality of local government financial statement. Therefore, based on the above deductions, the below hypothesis is postulated:

$\mathrm{H}_{3:}$ Implementasi of government accounting standard significantly and positively influences the quality of local government financial statements.

\section{DATA AND METHODOLOGY}

The research method used explanatory research surveys that describe the relationships between variables in the population under study, to explain the characteristics of the problem or phenomenon encountered. This type of research is verification that aims to determine the relationship between variables through hypothesis testing. The time period is cross sectional (Sekaran \& Bougie, 2013). This research was conducted by taking 75 local government unit tools of the 8 districts and city Banten Province of Indonesia. Analysis of data study using multiple regression analysis.

The quality of financial statements is measured by qualitative characteristics indicators that are reliable, relevant, comparable and can be understood. These indicators in accordance to PP No. 71 of 2010. Furthermore, internal control system measured by the 5 components of internal control by COSO, (2013) which are: (1) Control environment, (2) risk assessment, (3) control activities, (4) Information and communication systems, and (5) monitoring.

Information technology is measured using question items adopted from (Aswar \& Saidin, 2018) with device indicators, financial data management and maintenance. Furthermore, the implementation of government accounting standards is measured by using question items adopted from Sari (2012) with indicators of the objectives of financial statements, accounting principles and financial reporting, elements of financial statements because these indicators refer to PP No. 71 of 2010. Furthermore, the five-point Liker Scale to be used in the questionnaire that has a range of choices from strongly disagree to strongly agree will be used in measuring the responses of the questions. The next section below explores finding and discussions.

\section{FINDINGS AND DISCUSSIONS}

Based on the sample selection process of respondents in accordance with those previously determined using cluster sampling, with a total sample of 75 questionnaires that will be used in this study from a total of 110 questionnaires distributed. The level of significance in this study was $0.05(a=5 \%)$. Significance test is done by comparing the value of $r$ arithmetic with $r$ table, where $d f=n-2=75$, then the critical number $r$ table obtained is equal to 0.2542 . The results show that all indicators have a Pearson correlation value greater than the value of $r$ table $>0.2542$, it means that the statement is valid. Then the reliability test was conducted. Reliability test is carried out on the basis of decision making if the Cronbach alpha value exceeds 0.70 then the statement of the variable is reliable and vice versa. 
Table 1: The Result of Coefficient of Determination $\left(R^{2}\right)$

\begin{tabular}{|c|c|c|c|}
\hline Model & $\mathbf{R}$ & $\mathbf{R}$ Square & Adjusted R Square \\
\hline 1 & .504 & .254 & .214 \\
\hline
\end{tabular}

Table 1, the results of the coefficient of determination test (R2), shows that the independent variable is the internal control systems. Information technology, and the implementation of government accounting standards are able to explain the dependent variable, namely the quality of local government financial statements of 0.214 or $21.4 \%$ while the remaining $78.6 \%$ is influenced by other factors not used in this study.

Furthermore, Multiple regression is performed to determine the effect of the independent variables on the dependent variable. The results of the regression analysis are in the form of coefficients for each of the independent variables or independent variables. This coefficient is obtained by predicting the value of the dependent variable or the dependent variable with an equation. The results of multiple regression in the Table 2 as follows:

Table 2: Multiple Regression Results

\begin{tabular}{|c|l|c|c|c|}
\hline \multirow{2}{*}{ Model } & \multicolumn{2}{|c|}{ Unstandardized Coefficients } & Standardized Coefficients \\
\cline { 2 - 5 } & B & Std. Error & Beta \\
\hline 1 & (Contant) & 28.970 & 5.436 & .425 \\
\hline & ICS & .286 & .081 & .127 \\
\hline & IT & .098 & .096 & .104 \\
\hline & IGAS & .036 & .045 & \\
\hline
\end{tabular}

Based on the Table 2 above, the equation for regression as follows:

$$
\text { QFS }=28.970+0.286 \text { ICS }+0.098 \text { IT }+0.036 \text { IGAS }
$$

The equation above shows a constant value of 28,970 . This states that the implementation of government accounting standards, information technology and internal control systems is considered constant. Hence, the average value of the quality of financial statements is 28,970 . This means that the quality of financial statements is 28,970 or can be interpreted to be an increase of 28,970 .

Internal control system has a positive 0.286 for regression coefficient, which means every unit increase in ICS, it is expected that 0.286 unit increase in the quality of financial statements, holding all other variables contant. Then, the regression coefficient for information technology is positive 0.098 , which implies that for every unit increase in IT, a 0.098 unit increase is expected in the quality of financial statements, holding all other variables constant. Futhremore, regression resuls shows that the implementation of government accounting standards is 0.036 . This states that if other variables remain but implementation of government accounting standards have a positive coefficient. The positive 0.036 is shows on the IGAS, in which every unit increase in the implementation of government accounting standards, holding all other variables constants.

The statistical t-test was conducted to find out whether the internal control systems, information technology and the implemention of government accounting standards have a significantly positive influences on the quality of local government financial statements.

Table 3: Regression Results and Hypothesis Testing

\begin{tabular}{|c|l|c|c|}
\hline Model & & t & Sig. \\
\hline 1 & (Constant) & 5,329 &, 000 \\
\hline & ICS & 3.634 & .000 \\
\hline & IT & 2,228 &, 009 \\
\hline & IGAS & 0.942 &, 532 \\
\hline
\end{tabular}

In this study, multiple regression analysis was carried out to investigate the relationship between the predicting variables and the outcome variable. Based regression result on the Table 3, indicated that internal control system is the best predictor that predicts the dependent variable with the result $(\mathrm{t}=3.634, \mathrm{sig}=0.000)$. The next predictor in order of significance is information technology with the result $(t=2,228$, sig=0.009). However, implementation of government accounting standards $(t=0,942$, sig $=0.532$ ) is not significantly related to quality of local government financial statements in Banten Province of Indonesia. In 
a nutshell, two out of the three predictors have significant influence on the dependent variable on the directional hypotheses o this study. Therefore, this result implies that the quality of local government financial statements is greatly determined by its internal control systems and information technology and hance, $\mathrm{H} 1, \mathrm{H} 2$ are supported, while $\mathrm{H} 3$ is rejected.

The represents th first hypothesis which states that: the effect of internal control systems on the quality of local government financial statements. As expected, the empirical result of this study shows a significant and positive relationship between intenal control systems and quality of local government financial statements. This finding consistent with the most previous studies which found that internal control systems has a positive and significant influence on the quality of financial statements (Angus \& Mohammed, 2011, Muhammed et al. 2011; Kewo \& Afiah, 2017; Sari, 2012). Therefore, this can be seen from the presence of an adequate internal control system for each accounting and revenue /expense accounting control system activities contained in the working unit in the Banten Province and this affects the quality of financial statement produced.

The second research hypothesis which states that: the effect of information technology on the quality of local government financial staements. The above finding is in line with past studies that investigated the influence of information technology on the quality of financial statements. The resuls found that information technology has a positive and significant relationship with the quality of financial statements (Liyan, 2013; Zadeh, Karkon \& Golnari, 2015; Medina-Quintero, Mora \& Abrego, 2015; Lim, 2013; Bakri, 2016; Sacer \& Oluic, 3013). This is implying for local government because the system determined does not experience many obstacles and looks unfamiliar to its users, so as the implementing it can support the reliable financial statements presentation.

To accomplish the third objective of this study, $\mathrm{H} 3$ was postulated as: the effect of implementation of government accounting standards on the quality of local government financial statements. This result implies that the implementation of government accounting standards is not consider by the local government in Banten province as a main factor that drives them to quality of financial statements. The results in line with Inapy and Martiningshi (2016), but do not support research conducted by Sari (2012), Sousa, et al (2012), Mahaputra \& Putra (2014). This is because the financial statements prepared by local governments do not always apply the same accounting treatment for every similar event from one period to another. This is generally due to the limited ability of human resources owned by local governments, lack of socialization and training, and systems or applications that do not support yet.

The next section offers a conclusion of the entire study. İ provides the main conclusions, implications of the research finding, limitation of the study and the future study sugesstions.

\section{CONCLUSION}

The main issue that motivates the conduct of this sudy is to provide an understanding of the influencing factors towards quality of local government financial satements in work of unit Banten Province. This promted the review of previous literature about quality of financial statements. Based on the problem statement and this leads to the formulation of the research hypotheses the influencing factors on the quality of financial staements in Banten province.

Based on the analysed data that was collected, the research concludes that two of the influencing factors (internal control system, information technology) use are significantly to quality of local government financial statements. However, the study could not establish the implementation of government accounting standards on the quality of local government financial statements. Government unpreparedness in the implementation of PP in 2010 related to the application of accrual-based accounting standards and financial reports prepared by local governments does not always apply the same accounting treatment for each event from one period to another.

The limitation of this study is only use the work of unit in Banten Province, it has not been able to provide generalized picture for the overall quality of information related to the financial statements of local governments. Furthermore, advived to local governments socialization and counseling related to PP No. 71 of 2010 so that local governments are better equipped to apply accrual-based accounting. And further study is advised to expand the object of study and testing other variables outside of the variables such as human resource competence, the role of internal audit. 


\section{REFERENCES}

Arens, A., Elder, R., \& Beasley, M. (2014). Auditing and Assurance Service: An Integrated Approach. 15th ed. Upper Saddle River, NJ: Pearson Education, Inc.

Bakri, (2016). Effect of the use of information technology and organization cultural of the quality accounting information system, Internatioal Journal Scientific Tecnology Research, 5 (4), 120-125.

Bastian, I. (2010). Akuntansi Sektor Publik. Yogyakarta: Erlangga.

Boynton, W., Jhonson, R., \& Kell, W. (2006). Modern Auditing. 8th ed. USA: Richard D. Irwin Inc.

Brookson, S. (2009). Understanding Accounts. London: Dorling Kindersley.

Cohen, S., \& Kaimenakis, N. (2011). Assessing quality of financial reporting through audit reports: The case of Greek municipalities. Global Business and Economics Review, 13(3-4), 187-203.

COSO. (2013). Internal Control Integrated Framework: Executive Summary. Durham, North Carolina: Corruption Perceptions Index; 2015. Available from: http://www.ransparency.rg.

Desimone, S. (2017). Internal Audit and Financial Reporting Quality in the Public Sector, Work. Pap. Coll. Holy Cross.

Government Regulation Number 24 of 2005. (2005). Government Acccounting Standard. Jakarta, Indonesia.

Government Regulation Number 71 of 2010. (2010). Government Acccounting Standard. Jakarta, Indonesia.

Government Regulation Number 56 of 2005. (2005). Information system of Local government. Jakarta, Indonesia.

Government Regulation Number 60 of 2008. (2008). Government Internal Control system. Jakarta, Indonesia.

Inapty, M.F, \& Martiningsih, RR. (2016). Pengaruh penerapan standar akuntansi pemerintah, kompetensi aparatur dan peran audit internal terhadap kualitas informasi laporan keuangan'. Akuntabilitas: Jurnal Ilmu Akuntansi. 9(1), $27-42$.

International Public Sector Accounting Standards (IPSAS). (2010). Conceptual framework for general purpose financial reporting by public sector entities. The International Federation of Accountants (IFAC). Available from: http://www.fac.rg.

Jonas, G., \& Blanchet, J. (2000). Assessing quality of finacial reporting. Accounting Horizons, 14(3), 353-363.

Konrath, L. (2002). Auditing Concepts and Applications: A Risk-Analysis Approach. 5th ed. United States of America: West Publishing Company.

Kewo, C. L., \& Afiah, N. N. (2017). International journal of economics and financial issues does quality of financial statement affected by internal control system and internal audit? International Journal Economic Finance Issues, 7 (2), 568-573.

Lim, F. P. C. (2013). Impact of information technology on accounting systems. Asia-pacific Journal Multimed. Serv. Converg. with Art, Humanit. Sociol, 3 (2), 93-106.

Liyan, L. (2013). The Impact of Information Technology on Accounting Theory, Accounting Profession, and Chinese Accounting Education Profession, and Chinese Accounting Education. Wuhan International Conference E-business (WHICEB) Proceedings. 103

Madison. (2010). Defining Financial Statements. Madison: R. Chad \& Co.

Mahaputra, I.U., \& Putra, I.W. (2014). Analisis faktor-faktor yang mempengaruhi kualitas informasi pelaporan keuangan pemerintah daerah'. E-Jurnal Akuntansi Unoversitas Udayana. 8 (2), 230-244.

Mardiasmo. (2009). Akuntansi Sektor Publik. Jakarta: Penerbit Andi.

Medina-Quintero, J. M., Mora, A. \& Abrego, D. (2015). Enterprise technology in support for accounting information systems: An innovation and productivity approach. Journal Information System Technology Management, 12 (1), 29-44.

O’Brien, J., \& Marakas, G. (2010). Introduction to Information Systems. 15th ed. New York: McGrew-Hill Irwin.

Sačer, M. I., \& Oluić, A. (2013). Information technology and accounting information systems' quality in Croatian Middle and large companies, Journal of Information and Organizational Sciences. 37 (2), 117- 126.

Sari. (2012). Pengaruh sistem pengendalian intern pemerintah, implementasi standar akuntansi pemerintahan, penyelesaian temuan audit terhadap kualitas laporan keuangan pemerintah daerah dan implikasinya terhadap penerapan prinsip-prinsip tata kelola pemerintahan yang baik. Indonesian Journal of Economics and Business. 116-124.

Sawyer, L. (2003). Sawyer's Internal Auditing: The Practice of Modern Internal Auditing. Altamonte Springs, FL: The Institute of Internal Auditors. 
Sekaran, U. \& Bougie, R. (2013). Research methods for business; A skill building approach $6^{\text {th }}$ ed. UK: John Wiley \& Sons.

Sousa, R.G., Vasconcelos, A.F, Caneca, R. L., \& Niyama, J.K. (2012). Accrual basis accounting in the Brazilian public secror: empirical research on the usefulness of accounting information'. Journal USP Congress of Controllership and Accounting. 24 (63), $219-230$.

Supreme Audit Board, (2017). Ikhtisar Hasil Pemeriksaan Semester II Tahun 2017. Jakarta.

Van Beest, F., Braam, B., \& Boelens, S. (2009). Quality of Fiancial Reporting: Measuring Qualitative Characteristics. NICE Working Paper 09108, April.

Warren, S. Carl., Reeve, M. J., \& Fess, E. P. (2005). Corporate Financial Accounting. South Western: Thomson.

Wood, F., \& Horner, D. (2010). Business Accounting Basics.United Kingdom: Pearson Education Limited.

Zadeh, M. H. K., Karkon, A., \& Golnari, H. (2015). The effect of information technology on the quality of accounting information system and its impact on the quality of accounting information. Research Journal Finance and Accounting, 3 (3), $061-076$. 